\title{
Formation of effective mechanism of pairwise interaction of regional innovation subsystem subjects in the conditions of spatial transformation
}

\author{
Natalya Petrukhina \\ Bryansk state technical University, 241035 Bryansk, 7a, Bulvar 50-let Octyabrya, the \\ Russian Federation
}

\begin{abstract}
Abstruct. The article presents the results of research on topical issues of the formation of an effective mechanism of pairwise interaction of the primary participants in the regional innovation subset: that is state, business, universities. A methodical approach to the formation of both componential composition of the regional infrastructure and information-communication platform is proposed. One of the problems is marked by a significant differentiation of socio-economic development of the country's regions. The negative consequence of the uneven regions' development is the low efficiency and effectiveness of scientific and educational institutions and congested researchers in regions so it results in preventing practical research outcomes application and development. To eliminate the disproportions an effective mechanism of pairwise interaction of the regional innovation subsystem subjects is proposed. Interaction takes place on the basis of objective resource flows, the number of which is determined in the process of functional matrix building that allows to determine the list of these flows: legal, information and consulting, sales, personnel, material and financial. The conclusion contains a proposal to create an information and consulting platform, as well as to bring into being all the tools of organizational and economic impact for improving the level of infrastructure components development.
\end{abstract}

\section{Introduction}

In the context of the ongoing transformational changes and existing sanctions pressure on the Russian Federation there is an urgent need to develop a systematic approach to grow technological capabilities of the country, as well as to strengthen the role of intellectual and 
human resources in the digital economy $[1,11]$. The solution of the strategic task aimed at forming a united economic area in Russia determines the evolvement of effective mechanisms for the regions' integration into united national space as one of the important priorities of state policy. The results of the study taking into account domestic experience in regard to socio-economic development problems existing in regions indicate that areas vary greatly according to distribution of natural and economic resources and as well as their rational use $[2,12]$. At the legislative level there have been taken some steps to show the necessity of the new structure creation aiming at territorial organization of the country. At the same time, the top officials of the country allot a task of scientific and technological Russian Federation development through to 2035 and among them there is a creation of necessary model concerning international scientific and technical cooperation ; providing conditions for the implementation of high-tech and productive research and development; making an appropriate system of communication in the field of science, technology and innovation, as well as ensuring the increase of public interest to innovations and arranging conditions for the high-end business development within a certain territory; producing an effective management system in the field of research and development, which will ensure high efficiency and relevance of elaboration and research. [6,8-10,14-15]. The abovementioned reasons give a chance to look for a new effective mechanism of interaction between the basic RIP participants in order to increase both: the level of GRP in the region and the country's GDP. Strengthening of coordination between the interacting participants of the regional innovation subsystem will contribute to the development of the region and create opportunities to move from subsidized regions to the leading ones. The main direction of regional innovative activity improvement is the formation of rational element structure in the innovative infrastructure that is the important connecting element of relationship hierarchy caused by paradigm of economic development change in our country and certain select areas. The analysis of a significant problem such as spatial and interregional differentiation $[3,9]$ is relevant because it will form an effective mechanism of interaction of the basic RIP participants in order to increase the level of GRP, as well as to offer tools of organizational and economic impact on the basic participants of the Bryansk region RIP, which will contribute to improving the level of development of its infrastructure components, taking into account the potential for network integration.

\section{Methods}

The study of conceptual approaches to the creation of an effective mechanism of interaction between the basic RIP participants was carried out on the basis of the system analysis through the systematization of modern theoretical approaches, collection and processing of statistical information.

Due to the fact that the socio-economic situation of the subject depends not only on its geographical location, but also on either presence or absence of certain competitive advantages, it is necessary to determine an effective mechanism of interaction of the basic RIP participants in order to increase the level of GRP and to offer tools of organizational and economic impact on the basic RIP participants of the Bryansk region.

\section{Results}

The results of the analysis suggest that there is a significant spatial differentiation in the effectiveness and efficiency of new knowledge development and innovative products 
creation, while the concentration of research potential takes place only in some regions of the CFD of Russia within the period of 2010 - 2015 [4-5,13]. They are shown in figure 1. The rating of innovative development of Russian Federation subjects and regions of the CFD is determined through the Russian regional innovation index (RRII), which includes an assessment using four groups of indicators (indices): the index of "socio - economic conditions of innovative activity" (ISEC), "scientific and technical potential" (ISTP), "innovation activity" (IIA) and "quality of innovation policy" (IQIP).

It is found that among eighteen regions of the CFD in 2015 the analysis of the innovative development rating indicator value in regard to subjects of the Russian Federation reveals the following: it is Moscow that ranks 1st ( 0.5361), the remaining five regions are on the wane, for example Kaluga region ranks 6th (0.4824), Moscow oblast14th (0.4133), Voronezh -15th (0.4127), Lipetsk -16th (0.4123), Belgorod - 18th(0.4020), they are the second ten in the development of regions. The remaining twelve regions are in the third ten: Tambov-25th (0.3805), Yaroslavl-28th $(0.3593)$, the fourth ten is presented by: Tver -32th (0.3453), Ryazan-33th(0.3275), Tula-37th (0.3348), the fifth ten is :Kursk42th (0.3311),Vladimir -43th(0.3309), Bryansk-47th (0.3117), the sixth is :Smolensk-56th $(0.3119)$, Ivanovo -57 th $(0.2967)$, Orel-60th $(0.2793)$, the seventh is presented by : Kostroma-76th (0.2352).

Figure 1 shows the value dynamics in Russian regional innovation index of RRII by regions of the CFD from 2010 to 2015.

The value of the index RRII
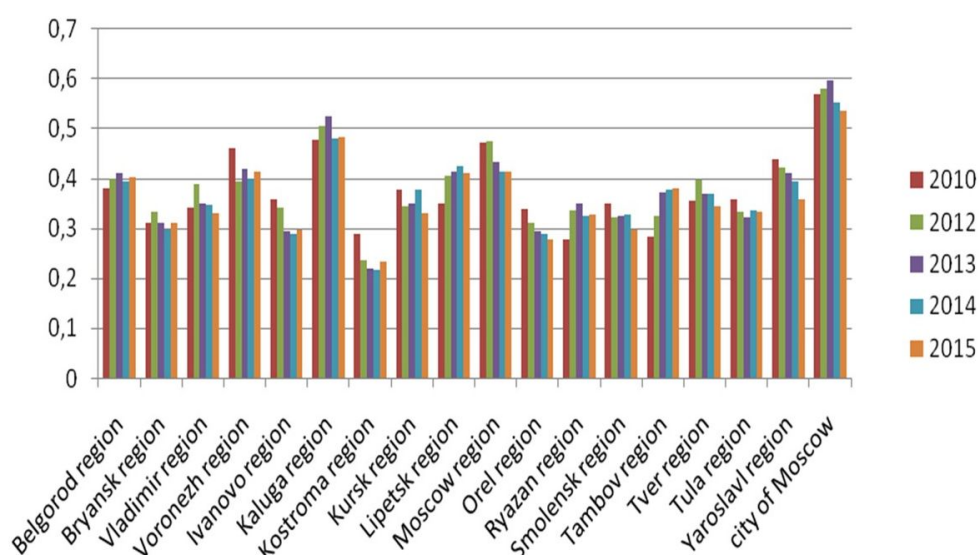

Fig. 1. Dynamics of the indicator of the Russian regional innovation index in regions of the CFD from 2010 to 2015

Thus, the transformation of the modern economy in Russia and its regions for the sake of scientific, technological and innovation development requires the definition of the need for the formation and functioning of a single scientific and technological space as the most important strategic goal, because it allows developing the principles of spatial development regulation of the national innovation system; creating mechanisms that prevent scientific, technical and innovative differentiation of regions and promote their integration into a single scientific and technological space; ensuring effective spatial distribution of scientific, technical and innovative resources; making systems for monitoring the functioning of the scientific and technological sphere of the regions; developing methods for assessing the level of scientific and technological sphere development in the regions and the processes of their interaction at the interregional level, which we lack at present. 
NIS in the aspect of its spatial transformation objectively is bent on the network form of their organization, which will reduce the influence of the territorial principle of the subject and contribute to the continuous process particularly it concerns both: the information interaction between the subjects of the network and joint activities in the field of creation and introduction of new technologies.

\section{Discussion}

From the functional approach standpoint there is an effective mechanism of pairwise interaction of the basic RIP participants that characterizes one participant behavioral path in relation to another. It allows to present such actions as subject resource flows, the number of which is determined in the process of functional matrix forming-up, which in its turn concerns the interaction between the state, universities and business, and makes such flows as legal, information and consulting, sales, personnel, material and financial possible to be included in the list..

In the process of research it is proved that if we proceed from the list of essential elements and principles of RIP formation, taking into account their potential for network integration, in this case such element as "relations and connections between the basic participants" is a methodological basis for the use of a functional approach to the development of a mechanism of pairwise interaction between the state, science (universities) and business, which characterizes the actions of one basic participant in relation to another. The set of such pairwise interactions of basic RIP participants should be presented as subject resource flows, which are included in the thesis and they are legal, information and consulting, sales, personnel, material and financial.

The main advantage of using a functional approach to characterize the actions of one basic RIP participant in relation to another is that it allows identifying the subject functions peculiar just to it.

Thus, the financial function performed by business in relation to the university and the financial function performed by the state in relation to the university are identical, while as for characteristics of performed activities, interests and their essence they differ greatly.

To solve the problem of determining the number and subject matter of resource flows, a functional matrix of pairwise interactions between the state, universities and business in the scientific and technological sphere has been developed and it is presented in table 2 .

Table 1 -a proposed functional matrix of pairwise interaction between the state, university and business

\begin{tabular}{|c|c|c|c|}
\hline & State(S) & Business(B) & University(U) \\
\hline 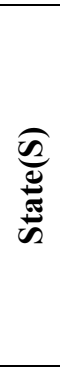 & $\mathrm{X}$ & $\begin{array}{c}\text { Quadrant (B-S) : } \\
\text { characterizes business } \\
\text { activity in relation to the } \\
\text { state, the totalityof which } \\
\text { form two objective } \\
\text { resourse } \\
\text { flows :marketingand } \\
\text { information-consulting } \\
\text { flow }\end{array}$ & $\begin{array}{l}\text { Quadrant(U-S) } \\
\text { characterizes university } \\
\text { activity in relation to the } \\
\text { state, the totalityof which } \\
\text { form two objective } \\
\text { resourse } \\
\text { flows :personnel, } \\
\text { information } \\
\text { andconsulting }\end{array}$ \\
\hline
\end{tabular}




\begin{tabular}{|c|c|c|c|}
\hline 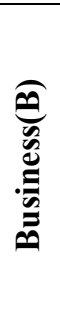 & $\begin{array}{l}\text { Quadrant (S- } \\
\text { B) :characterizes state } \\
\text { activity in relation to } \\
\text { business, the totalityof } \\
\text { which form two } \\
\text { objective resourse } \\
\text { flows :legal, material } \\
\text { and technical }\end{array}$ & $X$ & $\begin{array}{c}\text { Quadrant (U-S) : } \\
\text { characterizes university } \\
\text { activity in relation to the } \\
\text { state, the totalityof which } \\
\text { form two objective } \\
\text { resourse } \\
\text { flows :marketing and } \\
\text { personnel }\end{array}$ \\
\hline 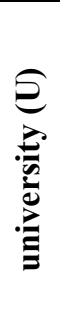 & $\begin{array}{c}\text { Quadrant (S-U): } \\
\text { characterizes } \\
\text { stateactivity in relation } \\
\text { to the university, the } \\
\text { totalityof which form } \\
\text { two objective resourse } \\
\text { flows :financial and } \\
\text { legal }\end{array}$ & $\begin{array}{l}\text { Quadrant (B-U) } \\
\text { characterizes business } \\
\text { activity in relation to the } \\
\text { university, the totalityof } \\
\text { which form two objective } \\
\text { resourse flows :financial, } \\
\text { material and technical } \\
\text { resourses }\end{array}$ & $X$ \\
\hline
\end{tabular}

As a result of the effective mechanism construction of pairwise interaction of the basic RIP participants there is the following functional interdependence of the state, university and business in relation to each other:

- university realizes personnel function and also stores financial function, which characterizes the relations both of business and of the state. Moreover, university performs a marketing function in relation to business transferring knowledge, ideas, developments, and in relation to the state it performs information and communication function;

- business actualizes information function in relation to the state, while it undertakes a marketing function that is put into effect by university, storing it and sending to the state (society) in the form of finished goods and products, works, services. University implements material and technical function in relation to business, while state puts into effect material and technical function in relation to business;

- state being the most active basic participant of the RIP realizes the legal function in relation to business and University by means of definition of priority directions of scientific, technical and innovation policy, while business and University in relation to the state realize information and consulting function.

Being an important structural component of the regional innovation system, the innovation infrastructure ensures the influence of all subjects on each other through these functions.

The key role of NIS organization network form is the ability to disseminate knowledge and information and that means contribution to the information interaction of RIPS, and then their joint activities in the process of network integration in the interests of scientific and technological development of the regional economy. The sphere of science, in its turn, desists to be autonomously functioning and becomes integrated into the network of scientific and technological space for achieving the goals of new knowledge digest and creation of innovative products.

In this regard, it is advisable to assert that the network form of NIS organization as well as creation of conditions for the network RIP integration. It gives the excellent opportunity to meet new technological challenges and generate new formats of cooperation and partnership for the development and implementation of new ideas together with introduction of breakthrough technologies. It allows determining the prospects for 
scientific, technical and innovative development at the regional level and it is interregional level that is really important.

The main advantages of the network approach to the formation of NIS in terms of its spatial transformation include:

- the ability of the national innovation system to respond to global challenges in the context of technological and resource changes;

- accessibility of knowledge, information, objects of innovative infrastructure to peripheral participants of network interaction;

- high probability of the territorial feature impact reducing of the development in the network of regional innovation subsystems, which currently reflects the spatial polarization of scientific and technological development in the regions.

\section{Conclusion}

The proposed effective mechanism of pairwise interaction of the basic RIP participants from the functional approach standpoint allows assessing the contribution of each of the participants in the socio-economic development of the region and also the level of either greatest or least impact of the state universities and business functional actions on the development of a particular infrastructure RIP component in a certain time period alongside with appreciating reserves for the development of scientific and technological sphere of the regions, permitting their entrance the trajectory of sustainable network integration. Analysis of Bryansk region innovation infrastructure forms showed that there is no any single organizational center for collecting information concerning both functioning of innovative enterprises having a detailed description of goods, works, services and making research or developments either for potential investors or innovative developments buyers.

The implementation of both: information development concept and consulting platform in the framework of the regional innovation subsystem formation in Bryansk region will allow to fulfill the items of the state program "Digital economy" for the development of information infrastructure elements, as well as to focus on improving the efficiency of regional organizations in the field of technology and innovation. Thus, the development of digital economy can have a significant impact on the rate of RF gross domestic product growth.

The instruments of organizational and economic effect on the basic RIP participants of Bryansk region, that provide for level increasing in its infrastructure components development and take into account the potential for network integration, are:

1.Consolidation of information and consulting infrastructure role by creating conditions for improving information interaction efficiency at the regional and interregional levels due to information layout and consulting platform placing in the area of the region.

2. Improvement of legal and regulatory infrastructure by means of legislation harmonization in the field of scientific and technological development of regions, taking into account their potential for network integration;

3. Advance of infrastructure financial block by identifying main directions of financing the participants of regional scientific and technological development, which allows the supporting of business structure in the region through state procurement.

4. Perfectibility of the material and technical block creating necessary institutes for technological development of the country in the territory of the region.

5. Improvement of the sales block by forming demand for innovations, placing orders for production and realization of necessary goods, works, services in the information base of RIP information and consulting platform. 
6. Betterment of human resources infrastructure through the development of human resources for the transition to the digital economy, the formation of an effective and competitive sector of research and development in the region, the possibility of creating a network of virtual research organizations, as well as the use of mechanisms of intra-elite rotation.

\section{References}

1. N. Kulagina, A. Bobryshev, S. Sulumov, L.Chaikovskaya, A. Smirnov. Research Journal of Pharmaceutical, Biological and Chemical Sciences, 9 ,6, 1321 (2018).

2. I.Risin, Y.Treshchevsky, L.Korobeynikova, V.Gavrilov. Management of Changes in Socio-Economic Systems, 135,21 (2018).

3. Bobryshev, N. Kulagina, N. Krivorotova, N. Logacheva, S. Noskin, Research Journal of Pharmaceutical, Biological and Chemical Sciences, 9, 6, 1290 (2018).

4. Y.Treshchevsky, P. Voronin, M. Tabachnikova, and G.. Franovskaya. Economic and Statistical Analysis in Evaluating the Perspectives of Structural Changes of Regions' Economy (Switzerland, Cham, Springer International Publishing AG,2018).

5. Y . Treshchevsky, G. Franovskaya,, D.Treshchevsky. Management of changes of socio-economic systems: Economic analysis of the state and consequences of the systemic feature (Switzerland, Cham, Springer International Publishing AG,2018).

6. V.Voronin, Y.Treshchevsky, M. Melnik, A. Sokolov. Analysis of risks of forecasted changes with the help of fuzzy logic elements (Switzerland, Cham, Springer International Publishing AG,2018).

7. Anzola-Román, C. Bayona-Sáez, T.García-Marco.Journal of Business Research, 91, $233(2018)$.

8. G. Shanks, M.Gloet, I. A. Someh, K. Frampton, T. The Journal of Strategic Information Systems, 27, 139 (2018).

9. T. Pankova, Y.Treshchevsky, E. Trakhtenberg. International Symposium Engineering Management and Competitiveness (16-17th June 2017; Zrenjenin; Serbia): Proceedings EMC2017. - Zrenjenin: Technical faculty “Mihajlo Pupin”, 249. (2017).

10. D. Endovitsky, M. Tabachnikova, Y. Treshchevsky. ASERS. Journal of Advanced Research in Law and Economics, VII, 6, 1745 (2017).

11. M.Tabachnikova, Y.Treshchevsky, G.Frankovskay, Y. Vertakova, O. Sogacheva. Globalization and its socio-economic consequences. $17^{\text {th }}$ International Scientific Conference. University of Zilina, The Faculty of Operation and Economics of Transport and Communications, Department of $4^{\text {th }}-5^{\text {th }}$ October 2017. Rajecke Teplice, Slovak Republic. YI. 2642 (2017)

12. N. Kulagina, F. Lozbinev, V. Kobischanov, N. Ivkina, Journal of Physics: Conference Series, 803, 1, 012084 (2017).

13. E. Strizhakova IOP Conference Series: Materials Science and Engineering. "International Conference on Mechanical Engineering, Automation and Control Systems 2015, MEACS 2015", 012097 (2016).

14. F. J. Buera, J. P. Kaboski Journal of Economic Theory, 147, 684 (2012).

15. S.-K. Peng, J.-F. Thisse, P.Wang Journal of Economic Theory, 131, 1 (2006). 